\title{
PLANT RESPONSE TO MECHANICAL RESISTANCE AND AIR-FILLED POROSITY OF SOILS UNDER CONVENTIONAL AND NO-TILLAGE SYSTEM
}

\author{
Alvaro Pires da Silva ${ }^{1 *}$; Silvia Imhoff; Beverley Kay ${ }^{3}$ \\ ${ }^{1}$ USP/ESALQ - Depto. de Solos e Nutrição de Plantas, C.P. 09 - 13418-900 - Piracicaba, SP - Brasil. \\ ${ }_{3}^{2} U N L$ - Cát. Diagnóstico y Tecnologia de Tierras, C.P. 3080 - Esperanza, SF - Argentina. \\ ${ }^{3} U G$ - Dept. Land Resource Science, C.P. N1G2W1 - Guelph, ON - Canada. \\ *Corresponding author <apisilva@esalq.usp.br>
}

\begin{abstract}
Roots may respond to restrictive soil physical conditions and send signals to shoots to control plant growth. Soil mechanical resistance and aeration can be managed to improve the soil physical conditions for plant growth by using different tillage systems. The objective of this study was to quantify the influence of no-tillage and conventional-tillage systems on plant response to soil mechanical resistance and aeration. The study was carried out on a farm, cultivated with corn, with a side-by-side comparison of no-tillage and conventional-tillage systems. Thirty-two paired sampling sites were located along two transects, located one in each treatment. Soil water content, bulk density, and plant growth were measured in each treatment. Based on the soil water and bulk density measurements, the air-filled porosity values were computed for each treatment. Soil water contents and bulk density values were converted to soil mechanical resistance by using the soil resistance curve. Plant growth varied positively with soil air-filled porosity, and negatively with soil mechanical resistance in both tillage systems. However, the decrease rates/increase rates were dependent on the tillage system. The no-tillage system somehow improved the soil physical conditions for the plants, especially when they were more restrictive, allowing them to attain greater values of growth.

Key words: plant growth, plant height, soil physical properties, tillage system
\end{abstract}

\section{RESPOSTA DE PLANTAS À RESISTÊNCIA MECÂNICA E POROSIDADE DE AERAÇÃO DE SOLOS SOB PREPARO CONVENCIONAL E PLANTIO DIRETO}

\begin{abstract}
RESUMO: As raízes podem responder à ocorrência de condições físicas restritivas no solo e enviar sinais parte aérea para controlar o crescimento da planta. A resistência mecânica e a aeração do solo podem ser alteradas para melhorar as condições físicas do solo para o crescimento das plantas por meio do emprego de diferentes sistemas de preparo do solo. O objetivo deste trabalho foi quantificar a influência dos sistemas preparo convencional e plantio direto na resposta das plantas da cultura de milho à resistência mecânica $\mathrm{e}$ aeração do solo. $\mathrm{O}$ estudo foi desenvolvido numa fazenda que apresentava uma parcela com preparo convencional localizada ao lado de outra sob plantio direto. Trinta e dois pontos de amostragem foram localizados através de duas toposeqüências, localizadas uma em cada tratamento. O conteúdo de água do solo, a densidade do solo e o crescimento, expressado como diferencia de altura, das plantas foram medidos em cada tratamento. Os valores de porosidade de aeração foram calculados com base na umidade do solo e os valores de densidade do solo. Os valores de umidade e de densidade do solo foram convertidos em valores de resistência mecânica por meio da curva de resistência do solo. $O$ crescimento das plantas variou positivamente com a porosidade de aeração e negativamente com a resistência mecânica do solo nos dois sistemas de preparo. Entretanto, as taxas de acréscimo/decréscimo foram dependentes do sistema de preparo do solo. $\mathrm{O}$ sistema plantio direto gerou condições físicas mais favoráveis às plantas, especialmente quando as propriedades do solo foram mais restritivas, permitindo-lhes atingir taxas de crescimento mais elevadas.

Palavras-chave: crescimento das plantas, altura das plantas, propriedades físicas do solo, sistema de preparo do solo
\end{abstract}

\section{INTRODUCTION}

Plant growth may be altered by a number of stress factors that are encountered by roots in their environment. Several researches have shown that soil mechanical re- sistance is one of the most important stress factors since it may control plant growth by reducing root elongation rate (Taylor \& Ratliff, 1969; Boone \& Veen, 1982; Veen \& Boone, 1990; Materechera \& Mloza-Banda, 1997; Zou et al., 2001). However, little is known about how soil me- 
chanical resistance may affect leaf and stem growth (Masle \& Passioura, 1987; Masle, 1990; Karunatilake et al., 2000; Passioura, 2002).

Another stress factor, the soil air-filled porosity, may also cause detrimental effects on plant growth (Voorhees et al., 1975; Drew, 1990; He et al., 1996; Grichko \& Glick, 2001; Zou et al., 2001). As the total air-filled porosity decreases to $10 \%$ or less, the oxygen diffusion rate into the soil is inhibited, causing injury to roots and their inability to function (Engelaar \& Yoneyama, 2000).

Pore size distribution and pore continuity play an important role in root growth by directly determining the soil volume filled with air and water, and indirectly the soil resistance. Furthermore, pore size distribution and pore continuity determine the ability to transport oxygen throughout the soil to the roots (Lipiec \& Hatano, 2003).

A favorable environment to plant growth may be obtained by reducing the soil stress factors. To this end, farmers have used many mechanical modification methods, usually known as tillage. Several papers have been published to highlight the influence of the tillage system on soil physical properties (Pagliai et al., 1995; Azooz et al., 1996; Ball-Coelho et al., 1998; Arshad et al., 1999).

Despite the benefits of tillage for crop establishment and production, the effects of different tillage systems on the relationships between soil mechanical resistance as well as aeration and plant growth remain almost underknown (Silva \& Kay, 1996; Arshad et al., 1999; Karunatilake et al., 2000). The objective of this study was to quantify the influence of both no-tillage and conventional-tillage systems on plant response to soil mechanical resistance and aeration.

\section{MATERIAL AND METHODS}

Field studies were conducted in 1991, 1992 and 1993 on a private farm located near Clinton, Ontario, Canada. The farmer had maintained a field scale side-byside comparison of no-tillage (NT) and conventional-tillage (CT) system, defined here as moldboard plowing in fall followed by cultivation in spring. A corn-soybeanwheat rotation had been used for 11 years on the site, which was only cultivated with corn during the experiment.

The comparison, in the form of a strip, crossed soils with a wide range in soil texture (from 58 to $374 \mathrm{~g}$ $\mathrm{kg}^{-1}$ of clay) and organic carbon content (from 9 to $39 \mathrm{~g}$ $\mathrm{kg}^{-1}$ ). Thirty-two plots ( $6 \mathrm{~m}$ long by $4.5 \mathrm{~m}$ wide) were established along parallel transects about $500 \mathrm{~m}$ length in each of the two tillage treatment to incorporate the systematic variation in soil texture and carbon content. Corn (hybrid 'Pioneer Brand 3751') was sown to a population that was double the normal density on 12 May, 1992, and 10 May, 1993. The plants were thinned to a population of 67,000 plants ha ${ }^{-1}$ about two weeks after emergence.
Plant growth and soil water content were simultaneously measured in each tillage treatment in 1992 and 1993, whereas soil bulk density was determined for all years. The 1992 and 1993 growing season were characterized as wet and dry, respectively. Details on the climate, soil properties, and crop management are given in Silva \& Kay (1997).

\section{Soil Measurements}

A total of two hundred and fifty six (2 tillage treatments $\times 32$ plots $\times 4$ replications) undisturbed cores ( $5 \mathrm{~cm}$ diameter by $2.5 \mathrm{~cm}$ length) were taken in 1991 from the surface layer $(5-7.5 \mathrm{~cm})$, where the effects of the tillage system would be more pronounced, to determine the soil resistance curve. A pedotransfer function was developed to relate soil resistance to penetration (SR) with clay content (CLAY), organic carbon (OC), and bulk density $\left(D_{b}\right)$ for each treatment. Details on this procedure are given in Silva \& Kay (1997). The SR model expressed in terms of soil properties was:

$$
\ln \mathrm{SR}=\ln c+d \ln \theta+e \ln \mathrm{D}_{\mathrm{b}}
$$

where: $\mathrm{SR}=$ soil resistance $(\mathrm{MPa}) ; \theta=$ volumetric water content $\left(\mathrm{cm}^{3} \mathrm{~cm}^{-3}\right) ; \mathrm{D}_{\mathrm{b}}=$ bulk density $\left(\mathrm{g} \mathrm{cm}^{-3}\right) ; c, d$, and $e$ are constants. The value of these constants can be obtained by using the following equations:

$$
\begin{aligned}
& \ln c=-3.673-0.145 \mathrm{CLAY}+0.765 \mathrm{OC}, \\
& d=-0.481-0.124 \mathrm{CLAY}+0.208 \mathrm{OC}, \\
& e=3.852+0.096 \mathrm{CLAY}
\end{aligned}
$$

where: $\mathrm{CLAY}=$ clay content $(\%) ; \mathrm{OC}=$ organic carbon content $\left(\mathrm{g} \mathrm{kg}^{-1}\right)$.

During the experimental periods of 1992 and 1993, four undisturbed cores $(5 \mathrm{~cm}$ diameter by $2.5 \mathrm{~cm}$ length) were taken from the $5-7.5 \mathrm{~cm}$ depth in the row and interrow positions in each plot of each tillage treatment for the $\mathrm{D}_{b}$ measurements. The earliest $\mathrm{D}_{\mathrm{b}}$ measurement was made at the 6-leaf stage and the latest at harvest. These individual values were averaged for each plot.

The soil water content was measured daily, in 1992 and 1993, using the time domain reflectometry (TDR) technique over the $0-0.2 \mathrm{~m}$ depth in the row and interrow positions at each plot in each of the two tillage treatments originating one hundred and twenty eight measurements ( 2 tillage treatments $\times 32$ plots $\times 2$ positions). The values were averaged across position in each treatment.

The averaged $\mathrm{D}_{b}$ values and the averaged water content values, measured in the dry growing season, were used to calculate (equation 1) the SR values to be related to plant growth.

The averaged $\mathrm{D}_{b}$ values and the averaged water content values, measured in the wet growing season, were used to estimate the air-filled porosity values. These values were computed for each treatment as $\theta_{\text {sat }}-\theta_{\mathrm{i}}$, where $\theta_{\text {sat }}$ is the soil saturation water content (equal to the total 
porosity obtained from the $\mathrm{D}_{\mathrm{b}}$ and particle density values), and $\theta_{i}$ is the observed soil water content. The air-filled porosity values were related to plant growth.

\section{Plant growth versus air filled porosity}

The plant growth was obtained from the plant height measurements. The plant height was measured with a ruler as the distance from the soil surface to the tip of the extended youngest leaf that corresponded to the number $12 \pm 1$. The measurements were carried out in 1992, on Julian days 197, 198, and 202, on 3 randomly selected plants in each plot of the two tillage treatments. The plant growth (PG) between successive days was calculated as:

$\mathrm{PG}_{197-198}=$ (height ${ }_{\text {day198}}-$ height $\left.{ }_{\text {day197}}\right)$, and $\mathrm{PG}_{198-202}=$ (height ${ }_{\text {day202 }}-$ height ${ }_{\text {day198 }}$ ) $/ 4$.

The PG measurements of the 3 plants were averaged for each day-plot combination. The average variability (expressed in terms of coefficient of variability \pm error) across the field (all plots) was: $\mathrm{CV}\left(\mathrm{SLG}_{197-198}\right)=7 \pm$ $4 \%$ and $\mathrm{CV}\left(\mathrm{SLG}_{198-202}\right)=6 \pm 5 \%$.

In order to assess the relationship between PG and air-filled porosity (AFP) it was necessary to match both measurements with respect to time and plot of each tillage treatment. Therefore for $\mathrm{PG}_{197-198}$, the AFP was estimated as the interpolated AFP at day 197.5. Similarly the $\mathrm{PG}_{198-202}$ was paired with the interpolated AFP at day 200 . Thus, for both treatments a total of 128 pair of values were used to the analysis.

\section{Plant growth versus soil resistance}

The plant growth was obtained from the plant height measurements by using the methodology shown in the preceding item. The determinations were carried out in 1993, on Julian days 199, 200, 201, 202, 203, and 204. The PG measurements of the 3 plants were averaged in each day-plot combination. The average variability (expressed in terms of coefficient of variability \pm error) across the field was: $\mathrm{CV}\left(\mathrm{PG}_{199-200}\right)=5 \pm 3 \%$; $\mathrm{CV}\left(\mathrm{PG}_{200-}\right.$ $\left.{ }_{201}\right)=7 \pm 4 \% ; \mathrm{CV}\left(\mathrm{PG}_{202-203}\right)=8 \pm 416 ; \mathrm{CV}\left(\mathrm{PG}_{203-204}\right)=8$ $\pm 4 \% ; \mathrm{CV}\left(\mathrm{PG}_{200-201}\right)=7 \pm 4 \%$.

The relationship between PG and SR was established by pairing the measurements as follows: $\left(\mathrm{PG}_{199-200}\right.$ $\left.-\mathrm{SR}_{199.5}\right),\left(\mathrm{PG}_{200-201}-\mathrm{SR}_{200.5}\right),\left(\mathrm{SLG}_{201-202}-\mathrm{SR}_{201.5}\right)$, $\left(\mathrm{SLG}_{202-203}-\mathrm{SR}_{202.5}\right)$, $\left(\mathrm{SLG}_{203-204}-\mathrm{SR}_{203.5}\right)$. The SR val- ues at the refereed days were obtained by interpolation of the values calculated with equation 1 .

\section{Statistical Analysis}

Nonlinear regression analysis (SAS, 1991) was used to evaluate the relationship between SLG and both air-filled porosity and soil resistance.

\section{RESULTS AND DISCUSSION}

The results for the relationship between plant growth (PG) and air-filled porosity (AFP) for both tillage treatments are given in Table 1 . PG was positively and non-linearly related to AFP. The relationship was significant $(P<0.0001)$ in both tillage treatments. Both models' parameters were higher in the conventional-tillage (CT) than in the no-tillage (NT) system. The model accounted for $55 \%$ of the PG variability in the NT and $65 \%$ in the CT. The observed data and the fitted function are given in Figure 1 for both tillage treatments. There was no sudden critical limit of $0.10 \mathrm{~m}^{3} \mathrm{~m}^{-3}$ AFP below which PG became quickly inhibited. Moreover there was an AFP range from about $0.05 \mathrm{~m}^{3} \mathrm{~m}^{-3}$ to 0.15 $\mathrm{m}^{3} \mathrm{~m}^{-3}$ in which PG increased with increasing AFP, and over which PG changed from affected to unaffected, for both tillage treatments. The decreasing slopes of the curves indicate that the PG sensitivity to aeration decreases as AFP increases. Similar results were found by Voorhees et al. (1975) and Zou et al. (2001) for root growth.

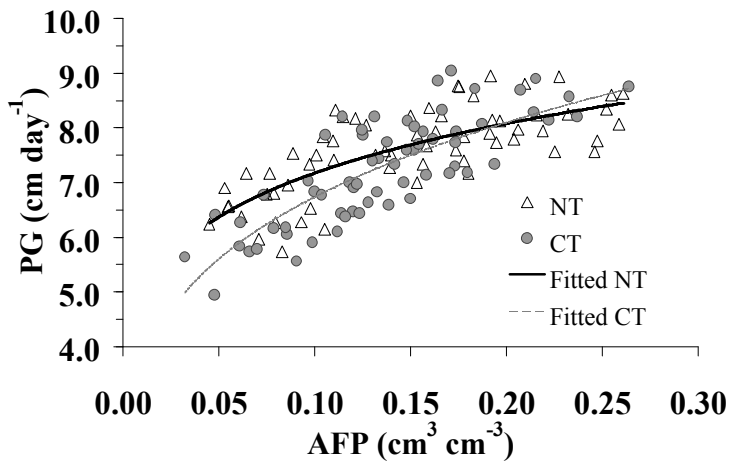

Figure 1 - Plant growth (PG) variation with air-filled porosity (AFP) for the no-tillage (NT) and conventional-tillage (CT) system.

Table 1 - Parameters estimate for the regresion relating plant growth (PG) and air-filled porosity (AFP) for the no-tillage (NT) and conventional-tillage (CT). PG $=\alpha$ AFP

\begin{tabular}{|c|c|c|c|c|c|c|c|c|c|c|}
\hline \multirow[b]{2}{*}{ Variable } & \multicolumn{4}{|c|}{ NT } & \multicolumn{4}{|c|}{$\mathrm{CT}$} & \multicolumn{2}{|c|}{ NT-CT } \\
\hline & $\begin{array}{c}\text { Parameter } \\
\text { estimate }\end{array}$ & $\begin{array}{c}\text { Standard } \\
\text { error }\end{array}$ & $\mathrm{t}$ & $\operatorname{Prob}>|t|$ & $\begin{array}{c}\text { Parameter } \\
\text { estimate }\end{array}$ & $\begin{array}{c}\text { Standard } \\
\text { error }\end{array}$ & $\mathrm{t}$ & Prob $>t$ & $\mathrm{t}$ & Prob $>\mid t$ \\
\hline$\alpha$ & 10.62 & 0.42 & 25.29 & 0.0001 & 12.64 & 0.68 & 18.59 & 0.0001 & -2.53 & 0.0141 \\
\hline$\kappa$ & 0.17 & 0.02 & 8.50 & 0.0001 & 0.27 & 0.03 & 9.00 & 0.0000 & -2.77 & 0.0074 \\
\hline & \multicolumn{4}{|c|}{$\mathrm{R}^{2}=0.55 ; \mathrm{N}=64 ; \mathrm{F}=76.53 ;$ Prob $>\mathrm{F}=0.0001$} & \multicolumn{6}{|c|}{$\mathrm{R}^{2}=0.65 ; \mathrm{N}=64 ; \mathrm{F}=113.31 ;$ Prob $>\mathrm{F}=0.0001$} \\
\hline
\end{tabular}


The tillage effect on PG depended on the magnitude of AFP. In most of the AFP range, PG was higher in the NT than in the CT. However the magnitude of tillage effect on PG increased as AFP decreased. At relatively high AFP the tillage effect was reversed. This behavior may be related to the differences on soil pore size distribution, which in turn are induced by the tillage systems. According to Pagliai et al. (1995) and Ball-Coelho et al. (1998), the NT system seems to lead to an increase in the water storage pores as well as in the largest transmission pores. Thus, the NT system may increase the water holding capacity, and simultaneously allow better water and air movement. The presence of the large scale pores may be responsible for the interaction tillageAFP:PG; i.e. the highest PG at low AFP in the soil under NT.

The decrease in PG due to low oxygen availability have been reported by Drew (1990), He et al. (1996), and Grichko \& Glick (2001). These authors found that hypoxia (partial $\mathrm{O}_{2}$ deficiency) promoted ethylene biosynthesis by roots. Another hormonal message to the shoots originated in the roots is absicic acid (ABA). Plants respond to these hormones with epinasty, stem hypertrophy, inhibition of stem and root growth, and leaf abscission. He et al. (1996) determined that hypoxia promoted aerenchyma formation on corn as a consequence of the elevated levels of ethylene on roots. These authors mentioned that roots subject to mechanical stress also exhibit an increase on ethylene levels, and that the two stresses acting together cause a synergistic promotion of ethylene biosynthesis. Voorhees et al. (1975) indicated that root sensitivity to air-filled porosity decreased with increasing soil aeration, probably due to the fact that as soil dries, the soil mechanical impedance becomes more limiting to root growth.

The relationship between PG and soil resistance (SR) was also non-linear, and it was described by the model given in Table 2. Plant growth was negatively and significantly $(P<0.0001)$ related to $\mathrm{SR}$ in both tillage treatments. Both regression parameters were significantly $(P<0.01)$ higher in the NT than in the CT. The observed data and the fitted function are given in Figure 2 for both tillage treatments. The model accounted for $43 \%$ of the PG variability in the NT and $75 \%$ in the CT.
Similarly to the air-filled porosity model, there was an interaction between tillage and SR on PG. Across the entire SR range the PG in the NT treatment was higher than in the CT. However, the magnitude of the effect increased with increasing soil resistance.

Weaich et al. (1992) found reduction in corn shoot elongation at high soil mechanical resistance. Vyn \& Raimbult (1993) also observed a negative relationship between corn growth and bulk density and soil resistance. Bristow \& Abrecht (1989) and Weaich et al. (1992) reported a negative relationship between corn shoot elongation and soil resistance. Moreover, Masle \& Passioura (1987) and Passioura \& Gardner (1990) observed a decrease in wheat shoot growth due to increase in soil resistance in experimental conditions with non-limiting conditions associated with water, nutrients and carbon supply. Plants may respond to unfavorable soil conditions by controlling their development, therefore making more carbon available for root growth. This may probably be a mechanism to increase the chance for roots to overcome the adverse soil condition as suggested by Masle et al. (1990). Researchers have suggested that a hormonal message is originated from the roots in soils with high soil resistance and sent to the leaf causing the reduction on shoot and leaf growth (Passioura, 2002).

Both relationships, i.e., (PG) vs (AFP and SR) indicated that plant growth does not stop even at values beyond the ones considered critical with respect to AFP

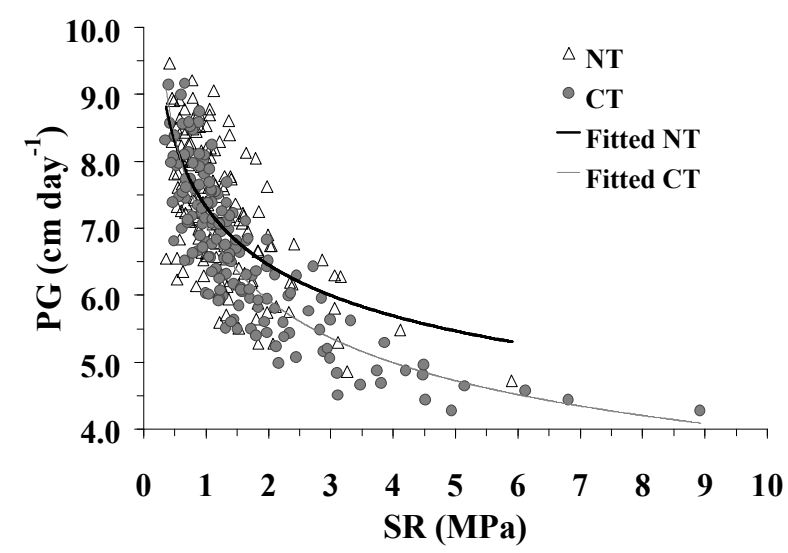

Figure 2 - Plant growth (PG) variation with soil resistance (SR) for the no-tillage (NT) and conventional-tillage (CT) system.

Table 2 - Parameters estimate for the regresion relating plant growth (PG) and soil resistance (SR) for the no-tillage (NT) and conventional-tillage $(\mathrm{CT}) . \mathrm{PG}=\gamma \mathrm{SR} \lambda$

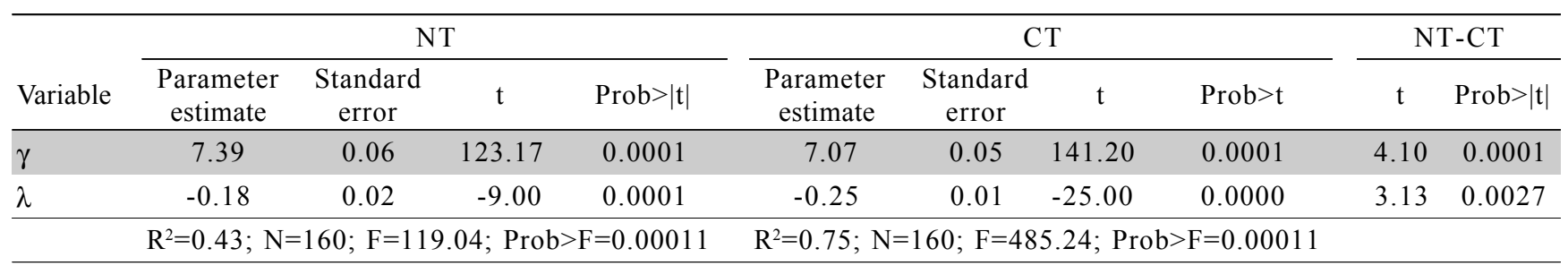


$\left(0.10 \mathrm{~cm}^{3} \mathrm{~cm}^{-3}\right)$ and SR $(2 \mathrm{MPa})$. The $2 \mathrm{MPa}$ critical limit was set to root growth (Taylor et al., 1966) and may not be adequate for shoot and leaf growth. However, the shoot growth sensitivity to soil resistance has been demonstrated by Masle \& Passioura (1987), who concluded that growth of roots was less affected than that of shoots.

It may be argued that the AFP and SR data were taken at the surface layer $(0-0.2 \mathrm{~m})$, and thereby the PG may be also associated with soil conditions of deeper soil layers. This is indeed a limitation of our data. However, our results may be supported by the findings of Saab \& Sharp (1989) with corn, and Blum et al. (1991) with wheat. In split-root experiments, they observed that the exposure of a relatively small part of a plant root system to a dry soil significantly reduced plant growth. Therefore, plant growth may be restricted by the most limiting soil layer regardless of how adequate the rest of the soil profile is. In addition, during the experiment trenches were open up to $1 \mathrm{~m}$ depth in 4 sites across the field. The overall observation was that the vast majority of the root system was located at the $0-0.2 \mathrm{~m}$ layer. The solum (A+B horizon) depth across the field ranges from $0.2 \mathrm{~m}$ to 1 $\mathrm{m}$, with average $0.49 \pm 0.23$.

For every plant response parameter evaluated the $\mathrm{R}^{2}$, i.e., the proportion of total variation about the mean of the dependent variable explained by the regression, was greater under the CT than the NT. Moreover, for a given level of stress, such as high SR or low AFP, the plant response was greater in the NT treatment than the $\mathrm{CT}$. The results may be related to the presence of soil biopores in the NT system as it was earlier mentioned. Ehlers et al. (1983) observed a negative linear relationship between soil resistance and oat root growth. Moreover the limiting penetration resistance for root growth was $3.6 \mathrm{MPa}$ in the tilled Ap-horizon and 4.9 $\mathrm{MPa}$ in the untilled Ap-horizon. They argue that this behavior may be due to the pores created by the soil fauna, which represent rooting pathways of low soil mechanical resistance. In fact, soil structure has a major impact on how root growth, and consequently PG, relates to SR, and the more common available techniques for measuring matrix soil properties do not take into account these large scale pores.

The biopores are normally beyond the range measured by standard techniques used to measure pore size distribution. Shipitalo \& Protz (1987) applied micromorphometric analyses to evaluate the effects of tillage on the porosity of soils planted with corn. They observed that Ap horizons of soils under NT had approximately half of the macroporosity of soils under CT. However, they indicated that soils under NT had two to nine times more biopores than soils under CT. Karunatilake et al. (2000) also found higher leaf biomass production in NT. They have mentioned that the numerous failure zones associated with the well-structured soil in NT helped to overcome the higher soil mechanical resistance observed in this system.

These biopores may be particularly important when the soil matrix has poor physical conditions such as high SR. Under these circumstances root growth may be strictly dependent on the presence of the biopores since by using these biopores roots can bypass the zones of high mechanical impedance (Lipiec \& Hatano, 2003). The biopores may then be related with the observed interaction tillage-SR:PG, i.e., the highest PG at high SR in the soil under NT.

One important implication of the influence of the tillage system on the soil physical condition, i.e. on soil mechanical resistance and aeration, is that the presence of large scale pores in soils under NT would lead to the increase on the SR and the decrease on the AFP critical values. The continuous PG variation with either AFP or SR suggests that the adoption of critical values for airfilled porosity $(10 \%)$ or soil resistance $(2 \mathrm{MPa})$ may have a limited value. Specifically for this study $10 \%$ AFP would corresponded to a relative PG (PG /maximum PG) of $80 \%$ and $75 \%$, for NT and CT, respectively. Soil resistance of $2 \mathrm{MPa}$ would imply in a relative PG of $69 \%$ for the NT and $65 \%$ for the CT.

For the specific cases of air-filled porosity and soil resistance it may be more realistic to look forward to limits based on relative plant growth. Instead of search for limits associated with growth/no growth or yield/no yield, it would be more appropriate to tie the critical limits with the percentage of reduction of a given plant response.

\section{CONCLUSIONS}

Plant growth was dependent on the soil physical properties and on the tillage system. The plant height increased with increasing air-filled porosity in a wet year, and decreased with increasing soil mechanical resistance in a dry year for both tillage systems. However, the tillage systems modified differently the soil physical conditions to plant growth since the increase rates/decrease rates of plant growth changed with them. Continuos longterm no-tillage system promoted higher plant growth at greater values of soil mechanical resistance and lower values of soil air-filled porosity than that reached for the plants in the conventional-tillage system.

\section{REFERENCES}

ARSHAD, M.A.; FRANZLUEBBERS, A.J.; AZOOZ, R.H. Components of surface soil structure under conventional and no-tillage in Northwestern Canada. Soil and Tillage Research, v.53, p.41-47, 1999. AZOOZ, R.H.; ARSHAD, M.A.; FRANZLUEBBERS, A.J. Pore size distribution and hydraulic conductivity affected by tillage in Northwestern Canada. Soil Science Society of America Journal, v.60, p.1197-1201, 1996. 
BALL-COELHO, B.R.; ROY, R.C.; SWANTON, C.J. Tillage alters corn root distribution in coarse-textured soil. Soil and Tillage Research, v.45, p.237-249, 1998 .

BLUM, A.; JOHNSON, J.W.; RAMSUER, E.L.; TOLLNER, E.W. The effect of a drying top soil and a possible non-hydraulic root signal on wheat growth and yield. Journal of Experimental Botany, v.42, p.1225-1231, 1991.

BOONE, F.R.; VEEN, B.W. The influence of mechanical resistance and phosphate supply on morphology and function of maize roots. Netherlands Journal of Agricultural Science, v.30, p.179-192, 1982.

BRISTOW, K.L.; ABRECHT, D.G. The physical environment of 2 semiarid tropical soils with partial surface mulch cover. Australian Journal of Soil Research, v.27, p.577-587, 1989.

DREW, M.C. Sensing soil oxygen. Plant, Cell, and Environment, v.13, p.681-693, 1990.

EHLERS, W.; KOPKE, U.; HESSE, F.; BOHM, W. Penetration resistance and root growth of oats in tilled and untilled loess soil. Soil and Tillage Research, v.3, p.261-275, 1983.

ENGELAAR, W.M.H.G.; YONEYAMA, T. Combined effects of soil waterlogging and compaction on rice (Oryza sativa L.) growth, soil aeration, soil $\mathrm{N}$ transformations and $\mathrm{N}$ discrimination. Biology and Fertility of Soils, v.32, p.484-493, 2000.

GRICHKO, V.P.; GLICK, B.R. Ethylene and flooding stress in plants. Plant Physiology, v.39, p.1-9, 2001.

HE, C.; FINLAYSON, S.A.; DREW, M.C.; JORDAN, W.R.; MORGAN, P.W. Ethylene biosynthesis during aerenchyma formation in roots of maize subjected to mechanical impedance and hypoxia. Plant Physiology, v.112, p.1679-1685, 1996.

KARUNATILAKE, U.; VAN ES, H.M.; SCHINDELBECK, R.R. Soil and maize response to plow and no-tillage after alfalfa-to-maize conversion on a clay loam soil in New York. Soil and Tillage Research, v.55, p.3142, 2000.

LIPIEC, J.; HATANO, R. Quantification of compaction effects on soil physical properties and crop growth. Geoderma, v.116, p.107-136, 2003.

MASLE, J. Growth and stomatal behaviour: response to soil resistance to root penetration. In: DAVIES, W.J.; JEFFCOAT, B. (Ed.) Importance of root and shoot communication in the responses to environmental stress. Bristol: British Society for Plant Growth Regulation, 1990. p.95113. (Monograph 21)

MASLE, J.; PASSIOURA, J.B. The effect of soil strength on the growth of young wheat plants. Australian Journal of Plant Physiology, v.14, p.643-656, 1987.

MASLE, J.; FARQUHAR, G.D.; GIFFORD, R.M. Growth and carbon economy of wheat seedlings as affected by soil resistance to penetration and ambient partial-pressure of $\mathrm{CO}_{2}$. Australian Journal of Plant Physiology, v.17, p.465-487, 1990.

MATERECHERA, S.A.; MLOZA-BANDA, H.R. Soil penetration resistance, root growth and yield of maize as influenced by tillage system on ridges in Malawi. Soil and Tillage Research, v.41, p.13-24, 1997.

PAGLIAI. M.; RAGLIONE, M.; PANINI, T.; MALETTA, M.; LA MARCA, M. The structure of two alluvial soils in Italy after 10 years of conventional and minimum tillage. Soil and Tillage Research, v.34, p.209-223, 1995.
PASSIOURA, J.B. Soils conditions and plant growth. Plant, Cell, and Environment, v.25, p.311-318, 2002

PASSIOURA, J.B.; GARDNER, P.A. Control of leaf expansion in wheat seedlings growing in drying soils. Australian Journal of Plant Physiology, v.17. p.149-157, 1990.

SAAB, I.N.; SHARP, R.E. Non-hydraulic signals from maize roots in drying soils: inhibition of leaf elongation but not stomatal conductance. Planta, v.179, p.466-474, 1989.

SAS INSTITUTE. SAS/STAT procedure guide for personal computers. 5.ed. Cary: SAS Institute, 1991. 1104p.

SHIPITALO, M.J.; PROTZ, R. Comparison of morphology and porosity of a soil under conventional and zero tillage. Canadian Journal of Soil Science, v.67, p.445-456, 1987.

SILVA, A.P. da; KAY, B.D. The sensitivity of shoot growth of corn to the least limiting water range of soils. Plant and Soil, v.184, p.323-329, 1996.

SILVA, A.P. da; KAY, B.D. Estimating the least limiting water range of soil from properties and management. Soil Science Society of America Journal, v.61, p.877-883, 1997.

SILVA, A.P. da; NADLER, A.; KAY, B.D. Factors contributing to temporal stability in spatial patterns of water content in the tillage zone. Soil and Tillage Research, v.58, p.207-218, 2001.

TAYLOR, H.M.; RATLIFF, L.F. Root elongation rates of cotton and peanuts as a function of soil strength and soil water content. Soil Science, v.108, p.113-119, 1969.

TAYLOR, H.M.; ROBERSON, G.M.; PARKER JR., J.J. Soil strength-root penetration relations for medium to coarse-textured soil materials. Soil Science, v.102, p.18-22, 1966.

VEEN, B.W.; BOONE, F.R. The influence of mechanical resistance and soil water on the growth of seminal roots of maize. Soil and Tillage Research, v.16, p.219-226, 1990.

VOORHEES, D.; FARREL, D.A.; LARSON, W.E. Soil strength and aeration effects on root elongation. Soil Science Society of America Journal, v.39, p.948-953, 1975.

VYN, T.J.; RAIMBAULT, B.A. Long term effect of five tillage systems on corn response and soil structure. Agronomy Journal, v.85, p.1074-1079, 1993.

WEAICH, K.; CASS, A.; BRISTOW, K.L. Use of a penetration resistance characteristic to predict soil strenght development during drying. Soil and Tillage Research, v.25, p.149-166, 1992.

ZOU, C.; PENFOLD, C.; SANDS, R.; MISRA, R.K.; HUDSON, I. Effects of soil air-filled porosity, matric potential and soil strength on primary root growth of radiata pine seedlings. Plant and Soil, v.236, p.105-115, 2001 .

Received December 05, 2003

Accepted June 17, 2004 